\title{
Aggressiveness in Adolescents Aged 15-18 Years Old, Under the Influence of Social Environment and the Introduction of New Technologies in Every Day Life.
}

Flora Lamcja (Zeqaj)

European University of Tirana, Albania, Tirana

flora.lamcja@yahoo.com

Armando Zeqaj

European University of Tirana, Albania, Tirana.

armandozeqaj@gmail.com

\section{Objectives:}

- To collect data and facts about the aggressiviness expression of adolescents aged 15-18, under the influence of social environment and the introduction of new technologies in everyday life.

- To draw conclusions about the influence of the above factors.

Hypothesis: The inappropriate social environment and the presence of the new technology in everyday life influence on the expression of the aggression by the young people.

The research question: Which is the connection that exists between the expression of the aggression and the social and technological environment in everyday life of adolescents aged 15-18years old.

\begin{abstract}
Agression is a difficult concept to define. It is used and misused widely (Scott 1975). People still argue about aggression. The social psychologist Robert Baron (1983), defines aggression as a behavior that intends to harm another who does not want to be harm. The aggressive behavior can be in various forms. It can be a physical or verbal behavior such as threats and it can be an indirect action. Aggression is a behavior, but it can be accompanied with emotion (anger) and it is influenced by emotions. Roger Johnson (1972) claimed that aggression is a concept with many forms and it can be influenced by many factors. Aggressive behaviors are present in the adolescents' daily routines by becoming a cause for reducing the quality of life, for different conflicts in the society even for the disruption of the internal disbalance. All these problems created the idea of a study in order to observe closely and to find which the problems of this aggression are and how this phenomenon can be prevented to the youth. In order to find out how does the social and technological environment effects on the increase of aggression to young people. This study is focued on the adolescents aged 15-18 by observing their different problems related to the manifestations of aggressive behaviors. The study's results corroborate the hypothesis abou the fact that the social and technological environment effects on the expression of aggression of the adolescents aged 15-18 (the sample of above study).
\end{abstract}

Keywords: Aggression, Influence, Adolescents, Social Environment, technology. 


\section{Theoretical concepts.}

Aggression is a behavior, but it can be accompanied with emotion( anger ) and it is influenced by emotions. Roger Johnson (1972) claimed that aggression is a concept with several dimensions and it can be influenced by many factors. Phsycologist have studied the relation between the aggression and other factors such as: heredity, sex, territory, echology, physiology, developments, learning and social organization. Theories about aggression. Aggression is studied in four perspectives: in the perspective of the theory instics, frustration-aggression theory, social learning theory and the social cognitive theory. The oldest theory about aggression claims that humans are aggressive from their nature. Probably the wellknown supporter of the old theory was Sigmund Freud (1930) who argued that aggression is the result of the instinct of death where all humans are born. Freud laid the idea when the negative powers increase they must be released through aggressive behaviors.

\section{Main sources of aggression based on the concepts of Freud:}

1) Dehumanization on the process of production and consumption. The technical progress is equal to the disappearance of the largest initiative, expectations, tastes and personal needs by offering goods and services. This trend is liberating if the available sources and techniques are used to relieve the man from work and enjoyment whichi are required for replication of the existing institutions if they are parasitic, useless and inhuman in comparison with the exisiting and intellectual technical opportunities.

2) The conditions of the crowd, the noise and manifestation and the characterstics of the mass society. As it is stated by Rene Dubo, the needs for "peace, privacy, independence, and initiative, and for some free space" are not "whims or luxuries, but they present the real biological needs". Their absence damages the insticual structure. Freud emphasized the "asocial" character of Eros, whereas the massive society reaches an "oversocialization" to which the individuals react "with all sorts of frustrations, oppression, aggression and fears".

The social usage of aggression belongs to the historical structure of civilization and it has been a powerful developing tool. However, there has been a stage when the amount can be turned into quality and it might subvert the normal balance between two primar instictics in favor of destruction. In fact, the real risk of the abundant society is the possible reduction of labour until to the level when the human organism would not need to function as a working tool. In order to fight against the capitalist mode of production (and against all exploitative ways of production) is sufficient the reduction of power needs of human labor.

The system reacts by developing the production of goods and services that do not expand the individual consumption, or expand with luxury goods, or luxury of persistent poverty, but it is the necessary luxury in order to keep busy with work the necessary power to reproduce existent political and economical institutions. In the moment when this kind of employment seems superfluous, senseless and unnecessary, but at the same time it seems necessary to earn enough money to survive, frustration appears to the productivity of this society and in this way the aggression is activated.

According to the degree of the aggression that the societies, even in their structure, adupts even the mental structure of citizens: the individual becomes in the same time, more aggressive, more pliable because it submitted a society which with its vain quality and power satisfies his deepest instinctive needs (which are otherwise the most pressing). Preparing for a disaster make people more calereless in spending money, more than if they were in the creation phase for constructive purposes. Why does this happen, I do not know, but I have noticed over a period in the Senat, that buying weapons to kill, to destroy things or cities and to wipe out cities has something that make people do not appreciate as it really is the dollar's value when they think for a new home or for the health care of human beings.

The most telling issue which distinguishes the new forms from the old ones, is that what is called aggression and technological fulfillment. The phenomena can be described shortly in this way: the act of aggression physically carried by a mechanism which has a high degree of automatization, with a bigger power of that of human who put its in the right functions. The most extreme case are the rockets and missiles, the most ordinary case of autmobolies. This means that the energy, the power which is activitated and consumed by that of mechanical, electrical or nuclear of the "item" and not the electrical instinctive of human beings. 
Therefore, the aggression will be transformed from the "subject to an object" or at least it will be "mediated" from the object and the target is destroyed by the item, not from the individual. This change in the relations between the human energy and that of material, physical part and that of human aggression (the man becomes the subject and the agent of aggression thorugh his mental abilities more than physical ones) should also affect even dhe mental dynamics. I set a hypothesis which is suggested by the inner logic of the process: by "deputing" the destruction to an object or to a set of things, more or less automatic, instinctual satisfaction of human beings is "interrupted", reduced, frustrated or "over hardened".

All these kinds of frustrations bring repition and escalation: increasing violence, speed and focus expansion. In the same time, the personal responsibility, awareness and the guilt feeble weaken or scatter, separate from the actual context where the aggression was created (for example, during the bombing) and it is set in a context more or less harmless (impolite behavior, sexual inadequacy etc). This reaction is due to a considerable weakening the sense of guilt, and even the defense ( (hatred or anger) is removed by the real responsible entity (the commanding officer, government) to a substitute person: therefore, I did not do it as an active individual (moral or physical) but the object, the machine. (Herbet Marcuse, 1967)

The machine: the word itself suggests that a device composed by human beings may be replaced from a mechanical device/apparatus: bureaucracy, administration, the party or organization is the responsible agent; whereas I, the invidual person, was just the vehicle, object. An object also can not take responsibility, in any moral sense, or can not be guilted all the time. Therefore, another barrier to the aggression is eliminated and the civilization has raised a long process of discipline. Moreover, the expansion of advancing capitalism is included in a fateful dialectic decision that comes and pushes forward the economical and political dynamics: the more powerful and "technological" the aggression is, the less convenient it is to satisfy and pacify the primary impuls, the more it tends toward repetition and escalation.

Naturally, the use of instruments of aggression is as old as the civilization itself, but there is a decisive difference between technological aggression and primitive forms. The latter were not quantitively different (weaker): they required activation or engagement of the body to a much higher degree than the automated and semi-automated instruments of aggression. The "knife" the blunt instrument, even the revolver are far more part of the indivual who uses them and they associate him more closely to his target. The technological aggression releases a mental dynamic which aggravates the destructive, antierotic tendencies of the puritan complex. The new ways of aggression destroy without getting the one's hands dirty, one's body soiled, one's mind incriminated. The killer remains clean phycially and mentally. The purity of his deadly work obtains added sanction if it is directed against the national enemy in the national interest.

The encroachment of aggression on the domain of the lifeinsticts and also devalues the aesthetic dimension. In Eros and Civilization I have tried to show the erotic component of this dimension. Nonfuctional, that is to say, not commited to the functioning of a repressive society, the aesthetic values have been strong protectors of Eros in civilization. Nature is part of this dimension. Eros seeks, in polymorphus forms, its own sensuous world of fulfillment, its own "natural" environment. But only in a protective world- protected from daily business, from noise, crowds, waste only thus can it satisfy the biological need for satisfaction (Herbet Marcuse, 1967). The aggressive business practices which turn eeven more of protective nature into a medium of commercial fulfillment or fund, thus do not merely effend beauty-they repress the biological necessities. Once we agreeto discuss the hypothesis that, in advanced industrial society surplus-aggression is released in quite unsuspected and "normal" behavior, then we may see it even in areas which are removed from the more familiar manifestations of aggression, for instance the style of publicity and information practiced by mass media.

The characteristic is the permanent repetition: the same advertisement, with the same text or picture is broadcasted or televised again and again: the same phrases or cliches poured out by the purveyors and makers of information repeatedly, the same programs and platforms professed by the politicians again and again. Freud created his concept of the death instinct in the context of his analysis of the "repetition compulsion": he associated this with the striving for a state of complete inertia, absence of tension, return to the womb and annihilation. Even in its less extreme use, constant repetition imposed upon more or less captive audiences, may be destructive: by destroying mental autonomy, freedom of thought, responsibility and conductive to inertia, submission, rejection of change. The 
established society which is the master of repetition becomes the great womb for the citiziens. In order to be sure, this road to inertia and this reduction of tension is one of high and not satisfactory sublimation: it does not lead to an instinctual nirvana of satisfaction. However, it may well reduce the stress of intelligence, the pain and tension which accompany autonomous mental activity- thus it may be an effective aggression against the mind in its socially disturbing, critical functions.

Moreover, the psychological impacts and the adaptation with the environment are lead towards physical threats to environmental effects such as climate change due to global warming which are inherent to the adaption of people towards them. Societies and individuals are affected by environmental threads or by the physical effects of global climate because these two elements, thus humanity and the environment can not be separated from each other.

\section{The methodology:}

Ky studim eshte bazuar ne metoden sasiore per mbledhjen e te dhenave e fakteve nga kampioni i perfshire ne studim. Per realiizimn e ketij studimi u perdoren instrumentet perkatese per mbledhjen e te dhenave rreth hipotezese ngritur ne studim. Keshtu u perdoren pyetesore dhe intervista me kampionet e perzgjedhur ne studim, dhe u siguruan nje sere te dhenash konkrete per temen e studimit. Me pas u realizua perllogaritja e tyre, duke dale ne perfundime e rezultate konkrete rreth studimit te kryer.

This study is based on the quantitive method for collecting the data and facts from the sample which is included in the study. For the realization of this study were used instruments for collecting relevant data about the hypothesis raised in the study. Therefore, there were used questionnaires and interviews with the selected study samples and provided a concrete number of data for the topic of the study. After that, it was calculation was conducted, by concluding the concrete results about the study.

Results of the study.

Table 1.

\begin{tabular}{|l|l|l|l|l|}
\hline $\begin{array}{l}\text { Adolescents aged 15- } \\
18\end{array}$ & $\begin{array}{l}\text { The expression of } \\
\text { aggression }\end{array}$ & $\begin{array}{l}\text { The level of } \\
\text { concentration }\end{array}$ & $\begin{array}{l}\text { The establishment of } \\
\text { social relations and } \\
\text { communication }\end{array}$ & $\begin{array}{l}\text { Show anxious } \\
\text { symptoms }\end{array}$ \\
\hline $\begin{array}{l}\text { Use with no criteria the } \\
\text { technology in their } \\
\text { everyday life. }\end{array}$ & $60-70 \%$ & $45-55 \%$ & $40-50 \%$ & $60 \%$ \\
\hline $\begin{array}{l}\text { Use of technology in } \\
\text { controlled ways. }\end{array}$ & $25-35 \%$ & $70-75 \%$ & $85-90 \%$ & $20 \%$ \\
\hline $\begin{array}{l}\text { The influence of social } \\
\text { environment on the } \\
\text { behaviors of } \\
\text { adolescents. }\end{array}$ & $65 \%$ & $70 \%$ & $80 \%$ & $40 \%$ \\
\hline
\end{tabular}

From the study it was found that the young people who use the new technology inappropriately by avoiding the natural pattern of human nature, present different problems in socialization, undermining the quality of daily life. These young people mostly manifest aggressive behaviors with their daily relationships; therefore they behave badly even with the people around them. They partially lose the verbal communication with the society and they have lack of concentration/focus on everyday problems, they lose interest of their tasks that they should complete. Some of them create a kind of dependency on technology, whereas some others feel a kind of anxiety in order to be adapted with the new technologies which are present in their everyday life. A particular effect on their behaviors has even the social environment where adolescents live. From this study it was found that the inappropriate social environment influences $65 \%$ of aggressive behaviors to adolescents, $70 \%$ in the level of their concentration, $40 \%$ in emergence of anxiety symptoms and $80 \%$ in the establishment of social relations and communication. This study comes to conclusion that the social environment plays a special role in 
the adolescents' behaviors, creating social relationships between them and the environment that surrounds them. The inappropriate social environment brings the emergence of these bad and deviant behaviors to adolescents. Furthermore, the usage of new technologies without any criteria causes the emergence of aggressiveness, anxious, lack of verbal communication with the society etc. The new technologies should be seen as an aid to human life and to adapt gradually with the social environment where we live without creating independence, without losing the natural pattern of human life.

\section{References}

Herbert Marcuse. Copyright 1968 by Herbert Marcuse. Translations from German copyright 1968 by Beacon Press. Reprinted by permission of Beacon Press, Boston.

Robert A. Baron (1983). The Control of Human Aggression: An Optimistic Perspective. Journal of Social and Clinical Psychology: Vol. 1, No. 2, pp. 97-119.

Roger N. Johnson. Aggression in man and animals. Saunders: Philadelphia, London, Toronto, 1972, pp. 22

Sigmund Freud, Civilization and Its Discontents (1930) New York: Norton, pp 94-105. 